\title{
Working hour mismatch, job quality, and mental well-being across the EU28: a multilevel approach
}

\author{
Xavier Bartoll ${ }^{1,2}$ \\ Raül Ramos ${ }^{3}$ \\ ${ }^{1}$ Agència de Salut Pública de Barcelona \\ ${ }^{2}$ Institut d'Investigació Biomèdica (IIB Sant Pau) \\ ${ }^{3}$ AQR-IREA, University of Barcelona, Barcelona, Spain
}

Corresponding author: Xavier Bartoll

xbartoll@aspb.cat

Telephone: (034) 932384545

Leseps num. 1

08012 Barcelona

Xavier Bartoll ORCID: 0000-0001-6865-8034

Raul Ramos ORCID: 0000-0003-0047-0793

\begin{abstract}
Objective

We aim to estimate the association between working hour mismatches and mental well-being. We also investigate the confounding and moderating role of job quality in this association.

Methods

We use cross-sectional data from the European Working Conditions Survey of 2015 in the analysis. The sample includes 9,345 male and 10,998 female employees in 28 countries. We run a multilevel linear regression accounting for the clustering of countries with mental well-being assessed by the World Health Organization Index. We compute mismatches in working hours as the difference between desired and actual hours of work, categorized as underemployed, unconstrained, and overemployed. The main dependent variable is the combination of these mismatches for each of the following working schedules: $\leq 20 ; 21-34$; 35-40; 41-47; and $\geq 48$ hours/week (h/w).
\end{abstract}

Results

The adverse association of short and long hours with well-being is mostly attributable to mismatches in working hours (except for men in the $41-47 \mathrm{~h} / \mathrm{w}$ group). Once we adjust for job quality, overemployed men $\geq 48 \mathrm{~h} / \mathrm{w}$ experience a reduction in mental well-being of -5.2 (95 CI\% -7.04 to -3.76$)$ with respect to the unconstrained base category $35-40 \mathrm{~h} / \mathrm{w}$. Overemployed women experience a reduction in mental well-being ranging from -4.94 (95 $\mathrm{CI} \%-6.54$ to -3.34$)$ in the $\geq 48 \mathrm{~h} / \mathrm{w}$ schedule to -11.11 (95 CI\% -17.35 to -4.87$)$ in the $\leq 20 \mathrm{~h} / \mathrm{w}$ schedule. We observe a confounding role of job quality across most working hour schedules, but the interaction effects are modest.

Conclusion

Employee control over working hours is associated with mental well-being with differences by gender. Labour policies aimed at promoting flexibility on the employee side could be favoured to improve workers' mental well-being.

Key words: Mental well-being, working hour mismatch, job quality, job intensity

\section{Funding}

Our research has received support from the Spanish Ministry of Economy and Competitiveness through project ECO2016-75805-R. The funding agency had no involvement in the research. 


\section{Introduction}

According to official estimates, $10.4 \%$ of employees work excessive hours - more than 48 hours per week (h/w) - and 28\% work short hours - fewer than 35 h/w (Eurofound 2017; ILO 2018). Mismatches between actual hours of work and desired hours of work may be due to overemployment, where actual hours exceed desired hours, and underemployment, where actual hours fall short of desired hours. These mismatches impose a loss of welfare for the worker. Person-environment fit theory (P-E) predicts that employee job performance and well-being will be higher where fit exists, and that a misfit between preferences and job characteristics will be particularly detrimental for employee well-being (Kristof-Brown et al. 2005). Where there is a lack of fit, the need for more (or less) work time reduces subjective well-being. Much of the literature on working hour mismatches has focused on the effects on job satisfaction, life satisfaction, and general health (see Bassanini and Caroli 2015 and Wunder 2016 for a summary of this literature). Few investigations focus on psychosocial problems, such as work stress and depressive symptoms (Constant and Otterbach 2011; Friedland and Price 2003; Angrave and Charlwood 2015; De Moortel et al. 2018), and only one paper directly addresses mental health and working hour mismatches in the European context (De Moortel et al. 2017). The issue is relevant, as recent estimates calculate that the cost of mental health problems across the 28 European countries is $4 \%$ of the GDP, or around 600 billion Euros, from which $1.6 \%$ of GDP or 260 billion Euros represents the cost of lower employment rates and lost productivity of people with mental health issues (OECD 2018).

On the other hand, psychosocial occupational models predict that greater job control and rewards, such as opportunities to engage in challenging tasks and learn new skills, buffer the impact of job demands on strain (Karasek 1979; Siegrist 1996). This type of jobs contrasts with jobs that combine high demands, low control, and low rewards leading to greater job dissatisfaction. Therefore, considering the role of job quality in the association between working hour mismatches and mental health allows us to analyse if this association is modified by heterogeneous jobs. It is expected that job rewards buffer (and job intensity worsens) the negative effects of under- and overemployment on mental health.

The objective of this research is to analyse the association between working hour mismatches with mental health and the role of job quality in this association. We use cross-sectional data from the 2015 European Working Conditions Surveys for 28 European countries.

\section{Background}

There is evidence of the adverse effects of long working hours on a variety of health outcomes (Sparks et al. 1997; van der Hulst 2003; Bannai and Tamakoshi 2014). More recently, the meta-analysis of Virtanen et al., (2018) finds support for an association between long working hours and the onset of depressive symptoms, but with heterogeneity, with a strong association in Asian countries, a weaker association in Europe, and no association in North America or Australia. However, few investigations analyse psychosocial health outcomes associated with mismatches in working hours. Friedland and Price (2003) find mixed results in their analysis of two waves of the Americans' Changing Lives Survey. The authors 
find that overemployed workers reported fewer depressive symptoms and lower levels of job satisfaction, while underemployed workers scored less in positive self-concept. They also report more instances of chronic conditions among workers with mismatches in working hours. In contrast, using data for the UK, Constant and Otterbach (2011) find negative effects of working hour mismatches on mental well-being and life stress among those working different schedules. Using two repeated cross-sectional surveys for 21 countries, De Moortel et al. (2017) find an association between involuntary long working hours and mental health for men and short and long hours for women. Therefore, although conclusions are limited by the comparability of these investigations, working hour mismatches are adversely associated with a variety of well-being and health outcomes. Bassanini and Caroli (2015) summarise the main message underlying the literature on working hour mismatches, concluding that it is not the work per se that is relevant for health outcomes, but not having control over the amount of work provided. Control over work has several benefits: it lessens work stress (Hall and Savery 1986), attenuates the adverse effects on health of long working hours (Sparks et al. 1997), increases the quality of sleep, and reduces work-family conflict (Barnett et al. 1999; Kubo et al. 2013; Lyness et al. 2012).

However, job quality is rather absent in most of the studies on working hours and working hour mismatches and health. This is a gap in the literature as from the seminal work of Rosen (1986) to recent study of Maestas et al. (2018) there is evidence that workers value job amenities that can have consequences in terms of well-being. The importance of controlling potential confounders and the potential modifying role of job quality has been highlighted (Ganster et al. 2018; Virtanen, et al., 2018). For instance, Otterbach (2010) and Knaus and Otterbach (2019) find that better job opportunities and an interest in one's job increase the probability of working the desired number of hours, while an exhausting, demanding, or stressful job decreases the probability of working the desired number of hours, with differences by gender. De Moortel et al. (2018), using two waves of the German socioeconomic panel, also find that overemployment worsens mental health, but they do not find the same for underemployment. Adding job rewards does not change the association between hour mismatches and mental health, and the interaction terms are not significant. Our analysis is different from that of De Moortel et al. (2018) in that we differentiate mismatches across working hours, as is common in the literature. We allow the interaction effects to differ among working hours, that is, that the effect of being overemployed in the rage of 35-40 h/w, for instance, may be different of that of working $41-47 \mathrm{~h} / \mathrm{w}, 48 \mathrm{~h} / \mathrm{w}$, or more. Moreover, we also take into account the effect of job intensity.

Country contextual factors also affect mismatches, including the level of public services for caring (Tsang et al. 2014), the availability of part-time employment, and the level of unemployment (Reynolds 2004; Del Boca 2002). In this respect, underemployment is more likely to occur in countries with higher unemployment rates and in countries with lower levels of institutional care (Otterbach 2010). Since unions fight for rewards and suitable work-family balance, countries with strong unions should have fewer workers with hour mismatches. According to this framework, we include trade union density, social per capita spending, and the share of unemployment and part-time employment as country level effects. 
To our knowledge, only three investigations use cross-country estimates: Otterbach (2010), BaŞlevent and KirmanoĞlu (2014), and De Moortel et al. (2017). The first author analyses country heterogeneity using fixed effect, and the latter two use multilevel models. Country-by-country analysis is impossible in our dataset due to the low sample size by country. A second option is to group countries according to criteria or adopt a welfare regime typology. However, given the multifactor nature of mismatches, country classification may poorly fit country heterogeneity. In this research, we use a multilevel technique as an efficient way to account for country variability given the sufficient number of countries to which it is applied (Bryan and Jenkins 2016). Taking all this into account and, as previously mentioned, the aim of this research is twofold. First, we aim to explore if the associations between working hours and mental well-being differ among unconstrained, overemployed, and underemployed workers. It is expected that mismatches are negatively associated with mental well-being, and that this negative association occurs to a lesser extent among unconstrained workers. Second, we aim to explore the role of job quality in this association.

\section{Methods}

\section{Data and population}

We use cross-sectional data from the $6^{\text {th }}$ European Working Conditions Survey (EWCS 2017) carried out in 2015. This is a multi-stage, regionally stratified random sample representative of the working population in each country. We exclude workers 26 years old and younger to limit the possibility that they are not fully available for the labour market. We also exclude workers aged 59 years and older, as workers close to the retirement age are more likely to adjust undesired working hours by taking early leave of the labour force (Charles and Decicca 2007). We also restrict our sample to workers declaring that they do not have daily limiting activities due to health problems to minimize the potential reverse causality problem. Workers with more than one regular job are also excluded, as their hours preference for their main job may be influenced by the hours of their second job. The final sample consists of 9,345 men and 10,998 women employees.

\section{Variables}

\section{Mental well-being}

Mental well-being is measured with the five-item World Health Organization Well-Being Index (WHO-5). It is used as a continuous variable to detect mild psychological mental distress with respect to mean population levels (Topp et al. 2015). The index is constructed adding the five-item scores, from 5 "All the time" to 0 "At no time" of the five responses and multiplied by four to get a percentage; 0 represents the worst possible well-being and 100 the best possible state. The systematic review of Topp et al. (2015) reports that the WHO-5 index has adequate psychometric properties. It also cites several studies that use the cut-off point $\leq 50$ as a 'screening diagnosis' for depression when exploring psychosocial problems related to work environment. Moreover, a $10 \%$ change is considered to be a significant variation in mental 
well-being (Addley et al., 2010; WHO, 1998). Our study obtains a satisfactory 0.878 Cronbach's alpha reliability for the five-item score. To assess the psychometric properties of the resulting scale, we compute a ratio scale model (RSM). The RSM constrains the difference between the difficulty parameters between adjacent categories to be equal across the items. The resulting RSM covers a wide range of the item difficulty spectrum, from to -2.37 to 1.49 , with an acceptable 1.77 of discrimination across items. The satisfactory fit of the model is assessed with the visual inspection of the characteristic curve (ICC) for overall items, which follows the empirical proportions closely.

Working hours mismatches

Desired working hours are obtained through the question: Provided that you could make a free choice regarding your working hours, and taking into account the need to earn a living, how many hours per week would you prefer to work at present? Actual working hours are obtained through the question: How many hours do you usually work per week in your main paid job? Hours of work are categorized as $\leq 20 ; 21-34$; $35-40 ; 41-47$; and $\geq 48 \mathrm{~h} / \mathrm{w}$. We use the standard schedule of $35-40 \mathrm{~h} / \mathrm{w}$ as the reference category. Mismatches in working hours are simply defined as the difference between actual and desired working hours. An employee is considered overemployed if the mismatch is greater than zero, underemployed if the mismatch is lower than zero, and matched/unconstrained if the difference is zero.

Job quality

We use the dimensions of job quality provided by the EWCS. These job quality dimensions are extensively documented in EWCS (2017), which can be summarised as follows: i) skills and discretion as intrinsic job quality (employees solve unforeseen problems independently and apply their own ideas, make decisions, participate in organisational decisions, have access to training, use technologies, and work as a team); ii) social environment, including social support (help and support from colleagues and managers, management quality, exposure to threats and discrimination); iii) physical environment (exposure to noise, dust, chemicals, or infectious agents; lifting heavy loads; repetitive hand movements); iv) job prospects (belief in the possibility of career advancement, job insecurity or fears about losing their job, possibility of downsizing in the organisation; v) job intensity / job demands (working quickly and with tight deadlines, not having enough time to do the job; frequent disruptive interruptions; pace determinants and interdependency; and emotional demands). We exclude the dimension of working time quality, because it overlaps with the variable related to hours of work. A previous factors analysis identifies job intensity as different from the other job dimensions, consequently job quality dimensions are reduced in two components: one component is job intensity, and the other component is obtained by confirmatory factor analysis based on intrinsic job quality, social environment, physical environment, and job prospects. The confirmatory factor analysis shows satisfactory goodness of fit: the standardized root mean residual of 0.033 , lower than the common criteria of 0.04 . This second component is labelled 'rewarding job.' We code tenure as 4 years or more (the base category), 2 to 3 years, and 1 year or less.

Country variables 
Country contextual variables are: unemployment rates; the share of part-time employment; the social protection benefits in purchasing power parity per inhabitant; and trade union density as of 2013. All sources are from Eurostat, OECD, and ILO.

Socioeconomic characteristics

Individual variables include age, age squared, being autochthonous (base category) or immigrant, and education level. Education level consists on the ISCED classification with categories of university (base category), tertiary education, upper secondary, secondary, and primary or less. Family type also influences desired hours of work and mental distress, especially when workers have children (Steiber and Haas 2019). Family variables include having children between the ages of 0-2, 3-6, 7-12, 13-17; the presence of disabled family members; the presence of relatives older than 70; living in a couple or not; not being a breadwinner (base category), being a breadwinner, or declaring oneself as an equally sharing breadwinner. Place of residence considers three possibilities: living in an urban area (base category), living in a rural area, or living in an intermediate area. Net monthly earnings in purchasing power parity are expressed in terciles. The $12.7 \%$ of missing values in this variable are imputed according to gender, age, age squared, number of adults and children at different ages in the household, civil status, education level, type of contract, occupation economic activity, and country. Information on occupation is based on the ISCO-08 at 1 digit while activity sectors are detailed in 10 categories from the NACE revision2.

\section{Empirical strategy}

First, descriptive statistics on actual versus desired hours and mismatches are reported with differences in mean scores of mental wellbeing for over- and underemployed workers compared to unconstrained workers, contrasted with a t-test.

Second, the association between working hour mismatches and mental well-being is estimated with a multilevel random effects model, where $i$ stands for individual and $j$ for country:

$$
\begin{aligned}
& M H_{i j}=\alpha_{o j}+\delta_{1} m_{i j}+\delta_{2 j r e w_{i j}}+\delta_{3 j i n t} t_{i j}+\delta_{4 j} \text { rew }_{i j} * m_{i j}+\delta_{5 j} j i n t_{i j} * m_{i j}+\delta_{6} x_{i j}+\varepsilon_{i j}(1) \\
& \alpha_{o j}=\alpha_{0}+\delta_{6} y_{i}+u_{j}(2)
\end{aligned}
$$

Here $M H_{i j}$ stands for the mental health WHO-5 index as a continuous variable, $m_{i j}$ is an index variable combining the five working hour categories $(\leq 20 ; 21-34: 35-40: 41-47: \geq 48 \mathrm{~h} / \mathrm{w})$ with the three potential situations in terms of working hour mismatches (overemployment, unconstrained, and underemployment); jrew $_{i j}$ stands for the rewarding job dimension and jint $t_{i j}$ for job intensity; jrew $w_{i j} * m_{i j}$ and $j i n t_{i j} * m_{i j}$ are the interaction terms; and $x_{i j}$ represents the vector of socioeconomic covariates and $\varepsilon_{i j}$ is the error term. The variability across European countries is accounted for by the random intercept $\alpha_{o i}$, that depends on a common intercept $\alpha_{\theta}$, country variables $y_{i}$, and $u_{j}$, which is the country random effect in equation (2). To account for the potential confounding role of job quality dimensions, we include job rewards and intensity and the interaction terms sequentially to the base estimation on working hour mismatches and covariates on well-being. The global significance of the interaction terms is contrasted with the likelihood test. 
Standard errors are computed with sandwich clustered estimates and a covariance matrix set to identity. All models are also stratified by sex. Weights for the EU28 were applied to all computations. As a robustness check, we replicate all models considering country as a fixed effect (data not shown). All computations were performed with Stata statistical software (version 15).

\section{Results}

Table 1 shows descriptive statistics of actual vs. desired working hours. Working in the range of 35 and 40 $\mathrm{h} / \mathrm{w}$ is the most common schedule among men (63.0\%) and women (48.9\%), but more men work longer than $48 \mathrm{~h} / \mathrm{w}(17.0 \%)$ than women (6.7\%). From this table, we can see a high proportion of matched employees working less than $40 \mathrm{~h} / \mathrm{w}$ (the highest in the range of $35-40 \mathrm{~h} / \mathrm{w}$ : $85.4 \%$ for men and $78.2 \%$ for women) and a consistent pattern for a desired reduction in working hours for those working more than 40 $\mathrm{h} / \mathrm{w}$. The proportion of men willing to work $35-40 \mathrm{~h} / \mathrm{w}$ among those working $41-47 \mathrm{~h} / \mathrm{w}$ is $47.8 \%$, and for of those working $\geq 48 \mathrm{~h} / \mathrm{w}$ it is $45.6 \%$. We see similar results for women: $49.8 \%$ and $54.0 \%$ among those in the range of $41-47 \mathrm{~h} / \mathrm{w}$ and $\geq 48$, respectively.

[TABLE 1 around here]

Table 2 shows working hours and mismatches for over- and underemployed workers (negative values indicate underemployment and positive indicate overemployment). Men and women working longer hours experience higher mismatches and poorer mental well-being compared to those working the standard schedule.

[TABLE 2 around here]

European employees are on mean overemployed above $9 \mathrm{~h} / \mathrm{w}$ for both sexes and underemployed between $11 \mathrm{~h} / \mathrm{w}$ for men and $12 \mathrm{~h} / \mathrm{w}$ for women. Unconstrained men and women enjoy higher levels of mental wellbeing (71.2 men and 69.7 women) compared to those who are overemployed (65.4 men and 62.0 women) and underemployed (68.0 men and 65.6 women). Across most categories, over- and underemployed women have lower mental well-being levels than their unconstrained counterparts. For men, lower mental wellbeing levels are concentrated in $35-40 \mathrm{~h} / \mathrm{w}$ and $\geq 48 \mathrm{~h} / \mathrm{w}$ schedules compared to their unconstrained counterparts.

Tables 3 and 4 combine the effect of working hours with working hour mismatches on mental well-being. The base model shows the associations between the combined variable and mental well-being, while the adjusted model additionally adjusts for job characteristics and the interaction model accounts for the interaction terms. Results for underemployed men and women with $41-47 \mathrm{~h} / \mathrm{w}$ and $\geq 48$ work schedules, and overemployed men working less than $\leq 34 \mathrm{~h} / \mathrm{w}$ are not shown due to the low sample size in this schedule. It is expected that unconstrained workers tend to work their chosen number of hours, and therefore are not associated with adverse health effects. Therefore, most of the associations between working hours and 
mental well-being will fall into the over- or underemployed categories but not into the unconstrained categories. This result obtains for men, except for those unconstrained in the 41-47 h/w schedule. We can interpret the results in Tables 4 and 5 with reference to the mean values of mental well-being for unconstrained men (67.2) working in the base category (35-40 h/w) in Table 2. For instance, overemployed men working $\geq 48 \mathrm{~h} / \mathrm{w}$ see a reduction in mental well-being of -5.2 points with respect to the unconstrained base category $(35-40 \mathrm{~h} / \mathrm{w})$ in the adjusted model. This implies a mean improvement of $8 \%$ from $5.6 \%$ to $10.4 \%$. It is also possible to compare the overemployed and unconstrained employees working $\geq 48 \mathrm{~h} / \mathrm{w}$ with analogous results. These values are close to the $10 \%$ significant change pointed to in previous literature (WHO, 1998). For overemployed workers, the reduction of well-being ranges from -4.45 points to -8.34 points in the base model. These magnitudes reduce from -2.25 to -5.36 in the adjusted model, which accounts for the confounding role of job quality. It is remarkable that the negative association of working $\geq 48 \mathrm{~h} / \mathrm{w}$ occurs only for overemployed workers but not for unconstrained workers. Rewarding jobs are positively associated with mental well-being $(0.70)$, but job intensity is inversely associated with mental well-being (-0.20). The likelihood ratio of the interaction terms is significant. Interestingly, job intensity appears to interact in a different direction for long hours: the interaction for unconstrained workers working 41-47 h/w worsens well-being (-0.25), but for those working $\geq 48 \mathrm{~h} / \mathrm{w}$ their well-being improves $(0.13)$. Coherently, the presence of job intensity for the overemployed at $\geq 48 \mathrm{~h} / \mathrm{w}$ reduces well-being $(-0.13)$ compared to the standard schedule. Nonetheless, the magnitudes of these interaction terms are of small value.

In the case of women, being either over- or underemployed is associated with a reduction of mental wellbeing across most working schedules. Overemployment implies greater reductions in mental well-being, in the range of -6.98 to -14.04 points in the base model, than underemployment, which implies well-being reductions in the range of -3.92 to -5.49 . Due to the confounding role of job quality, these magnitudes reduce in the adjusted model for overemployment to the range of -4.94 for those working $\geq 48 \mathrm{~h} / \mathrm{w}$ to -11.11 for those working $\leq 20 \mathrm{~h} / \mathrm{w}$ and becomes non-significant for underemployment. As mean mental well-being in the base category $(35-40 \mathrm{~h} / \mathrm{w})$ is 69.7 , as seen in Table 2, this implies that passing from overemployed $(41-47 \mathrm{~h} / \mathrm{w})$ to the unconstrained base category brings about an improvement in mental well-being of $9.4 \%$, from $4.6 \%$ to $14.3 \%$. Similar values would be obtained when comparing overemployed and unconstrained women working $41-47 \mathrm{~h} / \mathrm{w}$ (close to $10 \%$ significance, WHO, 1998). The association of mental well-being with a rewarding job $(0.67)$ and job intensity $(-0.22)$ is close to that of men. The likelihood ratio of the interaction terms is not significant.

Regarding the effect of contextual variables, country unemployment rates appear to contribute to better well-being for men and women, but the other contextual country variables are not significant.

[TABLE 3 around here]

[TABLE 4 around here] 


\section{Discussion}

Using cross-sectional data in a sample of European employees, we find that working hour mismatches are negatively associated with mental well-being in the case of over- and underemployed workers, with differences across genders. Mismatches explain most of the adverse associations of working hours for men and women. The inclusion of job quality dimensions considerably reduces the intensity of the association between working hour mismatches and mental well-being, which is a signal of a confounding effect. In particular, the interaction effect of job quality dimensions helps to explain favourable contributions to the well-being of voluntary versus involuntary long working hours for men.

The final job quality adjusted magnitude of the association of mismatches on mental well-being is larger for overemployed men working $\geq 48 \mathrm{~h} / \mathrm{w}$ and for women working $41-47 \mathrm{~h} / \mathrm{w}$ and $\leq 20 \mathrm{~h} / \mathrm{w}$. The difference in mental well-being with respect to their unconstrained counterparts is significant (around 10\%, WHO, 1998). However, we observe lower magnitudes of the association of mismatches on mental well-being for the standard schedule for the majority of working men $(35-40 \mathrm{~h} / \mathrm{w})$ : working hour mismatches reduce mental well-being between -2.2 points for overemployed men and -2.5 points for underemployed men in the adjusted model. Nonetheless, these values are above those reported by Bell et al. (2012) in self-assessed health for the UK and Germany (1.2 points in our equivalent 0-100 scale, the authors contextualise the relative importance of working hour mismatches as the analogous contribution of disability on life satisfaction), and above those reported by De Moortel et al. (2017) in involuntary long hours for mental well-being in 21 European countries (1.1 points for men and 1.5 points for women). Similar results are obtained by Wooden et al. (2009) when studying life satisfaction.

As noted in the previous literature (Constant and Otterbach, 2011), overemployment is a more frequent problem than underemployment, as it has an adverse effect across most working schedules. This is important, because a substantial proportion of European salaried workers (in our data, 29.2\% of men and $26.9 \%$ of women) are willing to work less (taking into account the need to earn a living), which is associated with poorer mental health. Underemployment is also problematic (in our data $9.9 \%$ for men and $13.1 \%$ for women), because it is a source of inequality and it mostly affects women engaged in short-term jobs. We expected that most associations between working hours and mental health would be removed for unconstrained employees and would fall below the over- and underemployment mismatches. This occurs in most cases, except for unconstrained men working $41-47 \mathrm{~h} / \mathrm{w}$, for which the association with poor wellbeing remains significant compared to unconstrained workers at $35-40 \mathrm{~h} / \mathrm{w}$. This result is also found by Constant and Otterbach (2011) who analyse stress and depression with fixed effects panel data. However, it is possible that other factors beyond working hours influence this association. A possible candidate is financial stress, which forces employees to work long hours. We do not account for financial stress in the estimation, as data is lacking. The observed average effects could also be due to unobserved personality traits and their interaction with the mismatch that explains the association. It is worth noting that for unconstrained men and women, working $\geq 48 \mathrm{~h} / \mathrm{w}$ is not associated with poorer mental well-being, but it is associated with being overemployed $\geq 48 \mathrm{~h} / \mathrm{w}$. Considering working hour and working hour mismatches sheds light on contradictory or mixed results found in previous studies on the negative association between 
very long working hours ( $\geq 48 \mathrm{~h} / \mathrm{w}$ ) and health outcomes (Watanabe et al. 2016). Our results add evidence in that the adverse mental health effects of very long working hours are nuanced according to the voluntary nature and degree of worker control of working hours. In this sense, the adverse effects of very long working hours are modified by active jobs, characterized by high job demands but high control, including control of working hours (Virtanen, 2018).

Considering working hour mismatches and job quality dimensions with their interactions, we have explored possible specification problems due to confounding and modifying effects (Ganster et al. 2018). A consistent confounding role for job dimensions is observed across most working hour schedules. Similar positive associations for job quality dimensions are obtained by Otterbach (2010) regarding job opportunities, skills, and good social environments and negative associations for the demanding job dimension. Unfortunately, the investigation of De Moortel et al. (2017) does not show results for job dimensions. This result warns us that not considering job quality may result in the overestimation of the negative associations of working hours and mismatches on health outcomes. However, the interaction effects are small, especially for job rewards. We expected that the positive association between job rewards and well-being would reduce with working hour mismatches. Conversely, we expected that the negative association between job intensity and well-being would increase. We observe no such associations for job rewards, and we only see an association with job intensity for overemployed men working $\geq 48 \mathrm{~h} / \mathrm{w}$. Unexpectedly, job intensity increases well-being among unconstrained men in the $\geq 48 \mathrm{~h} / \mathrm{w}$ regime, which can be interpreted as long working hours being used as a signalling mechanism on the employee side or as a screening mechanism for productive workers on the employer side (Sousa-Poza and Ziegler 2003). In contrast to these unconstrained men, well-being decreases among overemployed workers in the $\geq 48 \mathrm{~h} / \mathrm{w}$ regimes. It is clearer now that job intensity for men voluntarily working $\geq 48 \mathrm{~h} / \mathrm{w}$ is good but being involuntarily overemployed is bad for mental well-being.

Additionally, countries with higher unemployment rates appear to contribute to mental well-being. Similar results are reported for De Moortel et al. (2017) and BaŞlevent and KirmanoĞlu (2014). It is suggested that unsatisfactory employment conditions are less problematic in an adverse economic context.

\section{Strengths and limitations}

Due to the use of cross-sectional data, our results cannot be interpreted in terms of causality, although we restrict the sample to workers not affected by health problems. With longitudinal data, it would be interesting for future research to test adaptability or resolution rates of mismatches and to determine if there are differences by worker skills. However, a recent study shows that the mental health penalty of underand overemployment on mental well-being manifests after a relatively short time (Angrave and Charlwood 2015). In order to check the adequacy of WHO-5 as RSM, an item response theory (IRT) analysis has been performed with a satisfactory result. Nonetheless, a deeper analysis of the psychometric properties of the aggregate WHO-5 scale would be needed - a goal that goes beyond the possibilities of this paper. The research would also benefit from the incorporation of clear instruments on personality traits in the original 
survey. However, we are limited by the low sample size in some categories, making it difficult to check the sensitivity of results to alternative definitions of mismatches, for instance considering a gap between actual and desired hours below $\pm 4 \mathrm{~h} / \mathrm{w}$ for matches. The extensive literature on family economics highlights that preferences and employment status of the partner may also influence working hour mismatches and working hours supplied by the family as a whole, depending on the spouses' bargaining 'sharing rule' or altruistic/egoistic preferences. Unfortunately, we could not account for spouses' preferences due to a lack of information. Moreover, our estimates are obtained on the working population only, so the results are not generalizable to the whole potential working population. We argue that there is a sufficient number of countries in the multilevel estimates, although this is disputable due to the low sample size of 28 countries and in some categories in the combined variable. Despite the limitations of this study, we draw attention to the importance of reducing the extent of working hour mismatches, thereby improving well-being.

\section{Conclusion}

Besides the "good and bad job" quality divide, a working hour "mismatch divide" emerges in the sense that unconstrained workers enjoy better mental well-being for men across most schedules and women (except men in the 41-47 h/w regime). These results add evidence of the favourable consequences for employees of having control over their schedules and more flexibility from the labour supply side. Organizational flexibility could reduce the presentism of long working hours and low productivity. As long working hours are linked with overemployment, policies aimed at reducing long working hours also reduce overemployment and therefore the risk of poor mental health among workers. Increasing flexibility from the employee side could be introduced in collective bargaining as well as extending the individual right to request flexible work arrangements. 
References

Addley K, Burke C, McQuillan P. Impact of a direct access occupational physiotherapy treatment service. Occup Med (Chic Ill). 2010;

Angrave D, Charlwood A (2015) What is the relationship between long working hours, over-employment, under-employment and the subjective well-being of workers? Longitudinal evidence from the UK. Hum Relations 68(9):1491-1515. https://doi.org/10.1177/0018726714559752

Bannai A, Tamakoshi A (2014). The association between long working hours and health: a systematic review of epidemiological evidence. Scand J Work Env Health 40:5-18. http://doi:10.5271/sjweh.3388

Barnett RC, Gareis KC, Brennan RT (1999) Fit as a mediator of the relationship between work hours and burnout. J Occup Health Psychol 4:307-317. http://doi.org/10.1037/1076-8998.4.4.307

BaŞlevent C, KirmanoĞlu H (2013) The impact of deviations from desired hours of work on the life satisfaction of employees. Soc Indic Res 118:33-43. http://doi.org/10.1007/s11205-013-0421-9

Bassanini A, Caroli E (2015) Is Work Bad for Health? The Role of Constraint versus Choice. Annals of Economics and Statistics 13. http://doi.org/10.15609/annaeconstat2009.119-120.13

Bell D, Otterbach S, Sousa-Poza A (2012) Work hours constraints and health. FZID Discussion Papers 106:36-2011. http://doi.org/10.2307/23646455

Bryan ML (2007) Free to choose? Differences in the hours determination of constrained and unconstrained workers. Oxford Econo Pap 59:226-252. http://doi.org/10.1093/oep/gp1033

Charles KK, Decicca P (2007) Hours flexibility and retirement. Econ Inq 45:251-267. http://doi.org/10.1111/j.1465-7295.2006.00009.x

Constant AF, Otterbach S (2011) Work Hours Constraints: Impacts and Policy Implications. IZA Policy Paper.

De Moortel D, Thévenon O, De Witte H, Vanroelen C (2017) Working hours mismatch, macroeconomic changes and mental well-being in Europe. J Health Soc Behav 58(2):217231. http://doi.org/10.1177/0022146517706532

De Moortel D, Dragano N, Vanroelen C, Wahrendorf M (2018). Underemployment, overemployment and deterioration of mental health: the role of job rewards. Int Arch Occup Environ Health 91(8):1031-9. https://doi.org/10.1007/s00420-018-1345-0

Eurofound (2017), Sixth European Working Conditions Survey - Overview report (2017 update). Publications Office of the European Union: Luxembourg. 
Eurofound. (2017). Working time patterns for sustainable work. Publications Office of the European Union: Luxembourg.

Friedland DS, Price RH (2003) Underemployment: Consequences for the health and well-being of workers. Am J Comm Psychol 32:33-45. http://doi.org/10.1023/A:1025638705649

Ganster DC, Rosen CC, Fisher GG (2018) Long Working Hours and Well-being: What wekKnow, what we do not know, and what we need to know. J Bus Psychol 33: 25-39. http://doi.org/10.1007/s10869-016-9478-1

Hall K, Savery LK (1986) Tight reign, more stress. Harvard Bus Rev 64:160-164.

ILO (2018) Working time and the future of work. International Labour Office: Geneva.

Karasek RA (1979) Job demands, job decision latitude, and mental strain: Implications for Job Redesign. Admin Sci Quart 24(2):285-308. http://doi.org/10.2307/2392498

Knaus MC, Otterbach S (2019). Work hour mismatch and job mobility: adjustment channels and resolution rates. Econ Inq 57:227-242. http://doi.org/10.1111/ecin.12586

Kubo T, Takahashi M, Togo F, Liu X, Shimazu A, Tanaka K, Takaya M (2013) Effects on employees of controlling working hours and working schedules. Occup Med 63: 148151. http://doi.org/10.1093/occmed/kqs234

Kristof-Brown AMYL, Zimmerman RD, Johnson EC (2005) Consequences of individuals' fit. Pers Psychol 58(2):281-342. http://doi.wiley.com/10.1111/j.17446570.2005.00672.x\npapers3://publication/doi/10.1111/j.1744-6570.2005.00672.x

Lyness KS, Gornick JC, Stone P, Grotto AR (2012) It's All about Control: Worker Control over Schedule and Hours in Cross-National Context. Am Sociol Rev 77(6):102349. https://doi.org/10.1177/0003122412465331

Maestas N, Mullen KJ, Powell D, von Wachter T, Wenger JB (2018) The value of working conditions in the united states and implications for the structure of wages. NBER Working Paper Series. WP 25204. http://doi.org/10.3386/w25204

OECD (2018) Health at a Glance: Europe 2018. http://doi.org/10.1787/health_glance_eur-2018-en

Otterbach S (2010) Mismatches between actual and preferred work time: Empirical evidence of hours constraints in 21 countries. J Consum Policy 33:143-161. http://doi.org/10.1007/s10603-009-9116-7

Rosen S (1986) The theory of equalizing differences. Handbook of Labor Economics. http://doi.org/10.1016/S1573-4463(86)01015-5

Siegrist J (1996) Adverse health effects of high-effort/low-reward conditions. J Occup Heal Psychol 1(1):27-41. 
Sousa-Poza A, Ziegler A (2003) Asymmetric information about workers' productivity as a cause for inefficient long working hours. Labour Econ 10:727-747.

http://doi.org/10.1016/S0927-5371(03)00016-2

Sparks K, Cooper C, Fried Y, Shirom A (1997) The effects of hours of work on health: A meta-analytic review. J Occup Organ Psychol 70:391-408. http://doi.org/10.1111/j.2044-8325.1997.tb00656.x

Steiber N, Haas B (2019) Too much or too little work? Couples' actual and preferred employment patterns and work hours mismatches in Europe. Zeitschrift Für Familienforschung 30(3):269-292. http://doi.org/10.3224/zff.v30i3.03

Topp CW, Østergaard, SD, Søndergaard S, Bech P (2015) The WHO-5 well-being index: A systematic review of the literature. Psychother and Psychosom 84(3): 167-176. http://doi.org/10.1159/000376585

Tsang F, Rendall M, Rohr C, Hoorens S (2014). Emerging trends in earnings structures of couples in Europe: Short statistical report No. 5. Santa Monica: RAND Corporation. Retrieved: https://www.rand.org/pubs/research_reports/RR364.html.

van der Hulst M (2003). Long workhours and health. Scand J Work Env Health 29(3):171-88. http:// doi:10.5271/sjweh.720.

Wooden M, Warren D, Drago R (2009) Working time mismatch and subjective wellbeing. Brit Journal Ind Relat 47:147-179. http://doi.org/10.1111/j.14678543.2008.00705.x

Wunder C (2016). Working hours mismatch and well-being: Comparative evidence from Australian and German panel data. Annual Conference 2016 (Augsburg):

Demographic Change 145544. Retrieved:

https://ideas.repec.org/p/zbw/vfsc16/145544.html 
Table 1 Working hour mismatch: actual vs. desired

\begin{tabular}{lrrrrrrrr}
\hline & & \multicolumn{7}{c}{ Desired } \\
Actual & & $\%$ & $<=20$ & $21-34$ & $35-40$ & $41-47$ & $>=48$ & Total \\
Men & $\mathrm{N}=9,345$ & & & & & & & \\
$\leq 20$ & 374 & 4.0 & 48.9 & 6.7 & 41.8 & 0.4 & 2.2 & 100 \\
$21-34$ & 454 & 4.9 & 4.9 & 58.2 & 28.9 & 1.8 & 6.2 & 100 \\
$35-40$ & 5,894 & 63.0 & 1.7 & 9.4 & 85.4 & 1.7 & 1.8 & 100 \\
$41-47$ & 1,035 & 11.1 & 1.4 & 6.7 & 47.8 & 40.9 & 3.2 & 100 \\
$\geq 48$ & 1,588 & 17.0 & 1.4 & 4.4 & 45.6 & 6.8 & 41.8 & 100 \\
Women & $\mathrm{N}=10,998$ & & & & & & & \\
$\leq 20$ & 1,878 & 17.0 & 65.0 & 16.4 & 17.6 & 0.2 & 0.8 & 100 \\
$21-34$ & 2,308 & 21.0 & 6.8 & 77.6 & 14.7 & 0.4 & 0.5 & 100 \\
$35-40$ & 5,379 & 48.9 & 3.4 & 16.3 & 78.2 & 0.7 & 1.4 & 100 \\
$41-47$ & 697 & 6.3 & 2.3 & 13.2 & 49.8 & 33.7 & 1.0 & 100 \\
$\geq 48$ & 736 & 6.7 & 1.4 & 5.3 & 54.0 & 5.6 & 33.7 & 100 \\
\hline
\end{tabular}


Table 2 Distribution of working hour and mismatches, and mental well-being

\begin{tabular}{|c|c|c|c|c|c|c|c|c|c|c|c|c|}
\hline & \multicolumn{6}{|c|}{ Men } & \multicolumn{6}{|c|}{ Women } \\
\hline & \multirow[b]{2}{*}{$\%$} & \multirow{2}{*}{$\begin{array}{l}\text { Hour } \\
\text { mean }\end{array}$} & \multirow[b]{2}{*}{ sd } & \multicolumn{3}{|c|}{ Mental well-being } & \multirow[b]{2}{*}{$\%$} & \multirow{2}{*}{$\begin{array}{l}\text { Hour } \\
\text { mean }\end{array}$} & \multirow[b]{2}{*}{ sd } & \multicolumn{3}{|c|}{ Mental well-being } \\
\hline & & & & mean & sd & $\begin{array}{c}\text { p- } \\
\text { value }^{\mathrm{a}}\end{array}$ & & & & mean & sd & $\begin{array}{c}\mathrm{p}- \\
\text { value }^{\mathrm{a}}\end{array}$ \\
\hline \multicolumn{13}{|l|}{ Working hours } \\
\hline$\leq 20 \mathrm{~h} / \mathrm{w}$ & 4.0 & -11.3 & 12.3 & 70.8 & 19.0 & 0.687 & 17.0 & -6.7 & 10.6 & 68.1 & 19.8 & 0.568 \\
\hline $21-34 \mathrm{~h} / \mathrm{w}$ & 4.9 & -3.9 & 8.4 & 71.1 & 17.9 & 0.491 & 21.1 & -0.8 & 5.6 & 67.5 & 20.2 & 0.890 \\
\hline $35-40 \mathrm{~h} / \mathrm{w}$ & 63.0 & 1.2 & 4.7 & 70.2 & 18.1 & base & 48.9 & 2.1 & 5.7 & 67.6 & 19.7 & base \\
\hline $41-47 \mathrm{~h} / \mathrm{w}$ & 11.1 & 4.1 & 6.3 & 66.7 & 19.7 & 0.001 & 6.3 & 5.6 & 6.2 & 62.4 & 20.7 & 0.000 \\
\hline$\geq 48 \mathrm{~h} / \mathrm{w}$ & $\begin{array}{r}17.0 \\
100\end{array}$ & 8.9 & 9.5 & 65.5 & 20.5 & 0.000 & $\begin{array}{r}6.7 \\
100\end{array}$ & 10.1 & 9.5 & 64.5 & 19.2 & 0.005 \\
\hline Underemployed & 9.9 & -11.2 & 8.4 & 68.0 & 19.4 & 0.000 & 13.1 & -12.5 & 8.9 & 65.6 & 21.8 & 0.000 \\
\hline$\leq 20 \quad \mathrm{~h} / \mathrm{w}$ & 1.5 & -20.4 & 8.4 & 70.6 & 18.6 & 0.590 & 8.8 & -16.3 & 9.6 & 66.4 & 21.3 & 0.007 \\
\hline $21-34 \mathrm{~h} / \mathrm{w}$ & 2.6 & -12.6 & 5.9 & 68.7 & 18.8 & 0.084 & 13.8 & -8.8 & 4.7 & 69.2 & 19.5 & 0.045 \\
\hline $35-40 \mathrm{~h} / \mathrm{w}$ & 4.5 & -6.3 & 4.7 & 67.2 & 19.2 & 0.001 & 2.1 & -7.5 & 7.7 & 63.4 & 23.2 & 0.016 \\
\hline $41-47 \mathrm{~h} / \mathrm{w}$ & 0.4 & -7.9 & 4.6 & 68.8 & 21.4 & 0.869 & 0.1 & -9.1 & 4.0 & 51.7 & 34.4 & 0.310 \\
\hline$\geq 48 \quad \mathrm{~h} / \mathrm{w}$ & 0.3 & -10.8 & 9.1 & 66.6 & 14.9 & 0.362 & 0.0 & -7.6 & 3.7 & 65.6 & 18.0 & 0.298 \\
\hline Unconstrained & 60.9 & - & - & 71.2 & 17.9 & base & 60.0 & - & - & 69.7 & 18.5 & base \\
\hline$\leq 20 \quad \mathrm{~h} / \mathrm{w}$ & 2.3 & - & - & 72.3 & 19.6 & base & 7.4 & - & - & 70.7 & 17.5 & base \\
\hline $21-34 \mathrm{~h} / \mathrm{w}$ & 1.9 & - & - & 73.4 & 17.1 & base & 4.5 & - & - & 69.2 & 19.5 & base \\
\hline $35-40 \mathrm{~h} / \mathrm{w}$ & 44.5 & - & - & 67.2 & 19.2 & base & 33.1 & - & - & 69.7 & 18.5 & base \\
\hline $41-47 \mathrm{~h} / \mathrm{w}$ & 4.5 & - & - & 67.8 & 21.4 & base & 2.1 & - & - & 67.7 & 17.5 & base \\
\hline$\geq 48 \quad \mathrm{~h} / \mathrm{w}$ & 5.9 & - & - & 70.0 & 19.2 & base & 1.9 & - & - & 71.5 & 16.7 & base \\
\hline Overemployed & 29.2 & 9.8 & 7.3 & 65.4 & 19.7 & 0.000 & 26.9 & 9.7 & 6.7 & 62.0 & 20.8 & 0.000 \\
\hline$\leq 20 \quad \mathrm{~h} / \mathrm{w}$ & 0.2 & 5.3 & 5.9 & 61.5 & 17.6 & 0.037 & 0.8 & 6.1 & 5.3 & 55.2 & 23.1 & 0.001 \\
\hline $21-34 \mathrm{~h} / \mathrm{w}$ & 0.4 & 11.3 & 6.5 & 67.6 & 18.8 & 0.182 & 2.8 & 7.8 & 4.8 & 62.5 & 21.3 & 0.002 \\
\hline $35-40 \mathrm{~h} / \mathrm{w}$ & 14.0 & 7.3 & 5.9 & 67.2 & 19.2 & 0.000 & 13.8 & 8.9 & 6.1 & 63.1 & 20.8 & 0.000 \\
\hline $41-47 \mathrm{~h} / \mathrm{w}$ & 6.2 & 7.9 & 5.9 & 65.8 & 18.1 & 0.378 & 4.2 & 8.7 & 5.5 & 59.9 & 21.3 & 0.000 \\
\hline$\geq 48 \quad \mathrm{~h} / \mathrm{w}$ & $\begin{array}{r}10.8 \\
100\end{array}$ & 14.2 & 7.7 & 62.9 & 20.9 & 0.000 & $\begin{array}{r}4.7 \\
100\end{array}$ & 14.4 & 8.1 & 61.6 & 19.5 & 0.000 \\
\hline
\end{tabular}

${ }^{a}$ p-value contrasts the difference of mean well-being in each hour schedule of underemployment and overemployment mismatches respect to its base category counterpart; sd standard deviation 
Table 3. Multilevel linear random effects of working hours, working hour mismatches and job quality dimensions on mental well-being for men

\begin{tabular}{|c|c|c|c|c|c|c|c|}
\hline \multirow{2}{*}{ Men $(\mathrm{N}=9,345)$} & & \multicolumn{2}{|r|}{ Base } & \multicolumn{2}{|c|}{ Adjusted } & \multicolumn{2}{|c|}{ Interaction } \\
\hline & & estimates & $95 \% \mathrm{CI}$ & estimates & $95 \% \mathrm{CI}$ & estimates & $95 \% \mathrm{CI}$ \\
\hline \multirow{3}{*}{ Underemployed } & $\leq 20 \mathrm{~h} / \mathrm{w}$ & -0.19 & -3.74 to 3.36 & 2.47 & -2.29 to 7.23 & -0.52 & -3.92 to 2.87 \\
\hline & $21-34 \mathrm{~h} / \mathrm{w}$ & -1.49 & -6.03 to 3.05 & 0.83 & -2.82 to 4.47 & -0.39 & -3.36 to 2.57 \\
\hline & $35-40 \mathrm{~h} / \mathrm{w}$ & -3.76 & -5.93 to -1.59 & -2.53 & -5.06 to -0.00 & -2.73 & -5.21 to -0.26 \\
\hline \multirow[t]{5}{*}{ Unconstrained } & $\leq 20 \quad \mathrm{~h} / \mathrm{w}$ & 2.22 & 0.09 to 4.35 & 1.70 & -1.88 to 5.29 & 5.47 & 3.10 to 7.84 \\
\hline & $21-34 \mathrm{~h} / \mathrm{w}$ & 1.99 & -1.89 to 5.88 & 1.59 & -7.06 to 3.90 & 2.55 & -0.95 to 6.08 \\
\hline & $35-40 \mathrm{~h} / \mathrm{w}$ & base & & & & & \\
\hline & $41-47 \mathrm{~h} / \mathrm{w}$ & -3.31 & -5.17 to -1.45 & -3.26 & -5.28 to -1.24 & -2.72 & -5.37 to 0.78 \\
\hline & $\geq 48 \quad \mathrm{~h} / \mathrm{w}$ & -0.92 & -2.34 to 0.51 & -1.30 & -3.16 to 0.57 & -1.52 & -3.07 to 0.04 \\
\hline \multirow[t]{3}{*}{ Overemployed } & $35-40 \mathrm{~h} / \mathrm{w}$ & -4.45 & -5.84 to -3.06 & -2.25 & -3.79 to -0.70 & -2.32 & -3.78 to -0.86 \\
\hline & $41-47 \mathrm{~h} / \mathrm{w}$ & -5.19 & -7.85 to -2.53 & -2.47 & -4.94 to -0.03 & -1.92 & -5.07 to 1.22 \\
\hline & $\geq 48 \quad \mathrm{~h} / \mathrm{w}$ & -8.34 & -10.36 to -6.31 & -5.36 & -7.04 to -3.67 & -4.44 & -6.20 to -2.68 \\
\hline Job rewards (jrew) & & & & 0.70 & 0.59 to 0.81 & 0.73 & 0.66 to 0.80 \\
\hline \multirow[t]{3}{*}{ Underemployed } & $\leq 20 \mathrm{~h} / \mathrm{w} *$ jrew & & & & & -0.42 & -0.93 to 0.09 \\
\hline & $21-34 \mathrm{~h} / \mathrm{w} *$ jrew & & & & & -0.18 & -0.65 to 0.29 \\
\hline & $35-40 \mathrm{~h} / \mathrm{w} *$ jrew & & & & & -0.13 & -0.49 to 0.23 \\
\hline \multirow[t]{4}{*}{ Unconstrained } & $\leq 20 \mathrm{~h} / \mathrm{w} *$ jrew & & & & & 0.14 & -0.47 to 0.74 \\
\hline & $21-34 \mathrm{~h} / \mathrm{w} *$ jrew & & & & & -0.61 & -1.03 to -1.89 \\
\hline & $41-47 \mathrm{~h} / \mathrm{w} *$ jrew & & & & & 0.00 & -0.36 to 0.36 \\
\hline & $\geq 48 \quad \mathrm{~h} / \mathrm{w} *$ jrew & & & & & 0.12 & -0.27 to 0.51 \\
\hline \multirow[t]{3}{*}{ Overemployed } & $35-40 \mathrm{~h} / \mathrm{w} *$ jrew & & & & & 0.02 & -0.13 to 0.17 \\
\hline & $41-47 \mathrm{~h} / \mathrm{w} *$ jrew & & & & & -0.27 & -0.65 to 0.10 \\
\hline & $\geq 48 \quad \mathrm{~h} / \mathrm{w} *$ jrew & & & & & 0.16 & -0.08 to 0.39 \\
\hline Job intensity (jint) & & & & -0.20 & $-0.23--0.17$ & -0.17 & -0.20 to -0.14 \\
\hline \multirow[t]{3}{*}{ Underemployed } & $\leq 20 \mathrm{~h} / \mathrm{w} * \mathrm{jint}$ & & & & & 0.01 & -0.15 to 0.16 \\
\hline & $21-34 \mathrm{~h} / \mathrm{w} *$ jint & & & & & -0.10 & -0.35 to 0.14 \\
\hline & $35-40 \mathrm{~h} / \mathrm{w} *$ jint & & & & & -0.01 & -0.14 to 0.13 \\
\hline \multirow[t]{4}{*}{ Unconstrained } & $\leq 20 \quad \mathrm{~h} / \mathrm{w} * \mathrm{jint}$ & & & & & 0.37 & 0.04 to 0.70 \\
\hline & $21-34 \mathrm{~h} / \mathrm{w} *$ jint & & & & & 0.04 & -0.11 to 0.19 \\
\hline & $41-47 \mathrm{~h} / \mathrm{w} * \mathrm{jint}$ & & & & & -0.25 & -0.42 to -0.07 \\
\hline & $\geq 48 \quad \mathrm{~h} / \mathrm{w} *$ jint & & & & & 0.13 & 0.03 to 0.22 \\
\hline \multirow{3}{*}{ Overemployed } & $35-40 \mathrm{~h} / \mathrm{w} *$ jint & & & & & -0.03 & -0.16 to 0.10 \\
\hline & $41-47 \mathrm{~h} / \mathrm{w} * \mathrm{jint}$ & & & & & -0.08 & 0.24 to 0.08 \\
\hline & $\geq 48 \quad \mathrm{~h} / \mathrm{w} *$ jint & & & & & -0.13 & -0.22 to -0.05 \\
\hline
\end{tabular}




\begin{tabular}{|c|c|c|c|c|c|c|c|}
\hline \multirow{4}{*}{ Contextual } & Trade union density & 0.01 & -0.06 to 0.07 & 0.00 & 0.59 to 0.81 & 0.00 & -0.05 to 0.05 \\
\hline & Social spending & 0.00 & -0.00 to 0.01 & 0.00 & -0.00 to 0.00 & 0.00 & -0.00 to 0.00 \\
\hline & Unemployment & 0.11 & -019 to 0.41 & 0.32 & 0.03 to 0.60 & 0.32 & 0.04 to 0.61 \\
\hline & Part-time & 0.04 & -0.13 to 0.22 & 0.10 & -0.05 to 0.25 & 0.10 & -0.05 to 0.25 \\
\hline \multirow[t]{2}{*}{ Random effects } & Sd. Constant & 2.87 & 2.17 to 3.81 & 2.69 & 2.00 to 3.60 & 2.69 & 2.00 to 3.60 \\
\hline & Sd. Residual & 18.14 & 16.73 to 19.67 & 17.0 & 15.67 to 18.44 & $\begin{array}{l}16.87 \\
0.000\end{array}$ & 15.59 to 18.26 \\
\hline
\end{tabular}

All models adjusted by age, children, living with a partner, breadwinner, disabled/ill partner, older than 70 years, foreign born, urban, education level, earnings, tenure, occupation, economic sector.

LR-test comparing interaction and adjusted models

Omitted output for underemployment men and women above $40 \mathrm{~h} / \mathrm{w}$ and for overemployed man below $35 \mathrm{~h} / \mathrm{w}$ due to low sample size. 
Table 4. Multilevel linear random effects of working hours, working hour mismatches and job quality dimensions on mental well-being for women

\begin{tabular}{|c|c|c|c|c|c|c|c|}
\hline \multirow{2}{*}{ Women $(\mathrm{N}=10,998)$} & & \multicolumn{2}{|r|}{ Base } & \multicolumn{2}{|c|}{ Adjusted } & \multicolumn{2}{|c|}{ Interaction } \\
\hline & & estimates & $95 \% \mathrm{CI}$ & estimates & $95 \% \mathrm{CI}$ & estimates & $95 \% \mathrm{CI}$ \\
\hline \multirow[t]{3}{*}{ Underemployed } & $\leq 20 \mathrm{~h} / \mathrm{w}$ & -3.03 & -7.18 to 1.13 & -2.14 & -6.16 to 1.87 & -1.59 & -5.86 to 2.68 \\
\hline & $21-34 \mathrm{~h} / \mathrm{w}$ & -3.92 & -5.70 to -2.14 & -2.09 & -4.39 to 0.21 & -2.16 & -4.59 to 0.27 \\
\hline & $35-40 \mathrm{~h} / \mathrm{w}$ & -5.49 & -7.93 to -3.05 & -1.63 & -4.71 to 1.46 & -0.59 & -3.04 to 1.87 \\
\hline \multirow[t]{5}{*}{ Unconstrained } & $\leq 20 \mathrm{~h} / \mathrm{w}$ & -0.10 & -4.26 to 4.06 & -0.02 & -4.28 to 4.25 & 0.01 & -4.38 to 4.41 \\
\hline & $21-34 \mathrm{~h} / \mathrm{w}$ & -1.36 & -3.44 to 0.72 & -1.23 & -3.07 to 0.60 & -1.09 & -9.00 to -2.85 \\
\hline & $35-40 \mathrm{~h} / \mathrm{w}$ & Base & & & & & \\
\hline & $41-47 \mathrm{~h} / \mathrm{w}$ & -2.41 & -5.43 to 0.62 & -1.57 & -4.34 to 1.21 & -1.69 & -4.51 to 1.13 \\
\hline & $\geq 48 \mathrm{~h} / \mathrm{w}$ & 2.49 & -0.63 to 5.61 & 3.06 & -0.32 to 6.15 & 3.18 & 0.20 to 6.15 \\
\hline \multirow[t]{5}{*}{ Overemployed } & $\leq 20 \quad \mathrm{~h} / \mathrm{w}$ & -14.04 & -21.17 to -6.91 & -11.11 & -17.35 to -4.87 & -10.69 & -17.53 to -3.85 \\
\hline & $21-34 \mathrm{~h} / \mathrm{w}$ & -7.68 & -10.53 to -4.83 & -5.82 & -8.31 to -3.32 & -5.92 & -9.00 to -2.85 \\
\hline & $35-40 \mathrm{~h} / \mathrm{w}$ & -6.98 & -9.31 to -4.65 & -5.08 & -7.46 to -2.69 & -5.05 & -7.50 to -2.60 \\
\hline & $41-47 \mathrm{~h} / \mathrm{w}$ & -9.91 & -13.03 to -6.78 & -6.58 & -9.94 to -3.23 & -5.76 & -9.38 to -2.13 \\
\hline & $\geq 48 \mathrm{~h} / \mathrm{w}$ & -8.20 & -9.59 to -6.82 & -4.94 & -6.54 to -3.34 & -4.88 & -7.14 to -2.63 \\
\hline Job rewards (jrew) & & & & 0.67 & 0.56 to 0.77 & 0.75 & 0.64 to 0.85 \\
\hline \multirow[t]{3}{*}{ Underemployed } & $\leq 20 \mathrm{~h} / \mathrm{w} *$ jrew & & & & & 0.03 & \\
\hline & $21-34 \mathrm{~h} / \mathrm{w} *$ jrew & & & & & -0.11 & -0.24 to 0.30 \\
\hline & $35-40 \mathrm{~h} / \mathrm{w} *$ jrew & & & & & 0.07 & -0.24 to 0.38 \\
\hline \multirow[t]{4}{*}{ Unconstrained } & $\leq 20 \mathrm{~h} / \mathrm{w} *$ jrew & & & & & -0.45 & -0.78 to -0.11 \\
\hline & $21-34 \mathrm{~h} / \mathrm{w} *$ jrew & & & & & -0.19 & -0.53 to 0.15 \\
\hline & $41-47 \mathrm{~h} / \mathrm{w} *$ jrew & & & & & -0.00 & -0.27 to 0.23 \\
\hline & $\geq 48 \quad \mathrm{~h} / \mathrm{w} *$ jrew & & & & & -0.27 & -0.68 to 0.14 \\
\hline \multirow[t]{5}{*}{ Overemployed } & $\leq 20 \quad \mathrm{~h} / \mathrm{w} *$ jrew & & & & & 0.35 & -0.37 to 1.07 \\
\hline & $21-34 \mathrm{~h} / \mathrm{w} *$ jrew & & & & & 0.03 & -0.32 to 0.39 \\
\hline & $35-40 \mathrm{~h} / \mathrm{w} *$ jrew & & & & & -0.11 & -0.30 to 0.08 \\
\hline & $41-47 \mathrm{~h} / \mathrm{w} *$ jrew & & & & & -0.05 & -0.27 to 0.17 \\
\hline & $\geq 48 \quad \mathrm{~h} / \mathrm{w} *$ jrew & & & & & 0.02 & -0.18 to 0.21 \\
\hline Job intensity (jint) & & & & -0.22 & $-0.25--0.18$ & -0.19 & -0.26 to -0.12 \\
\hline \multirow[t]{3}{*}{ Underemployed } & $\leq 20 \mathrm{~h} / \mathrm{w} *$ jint & & & & & -0.00 & -0.14 to 0.13 \\
\hline & $21-34 \mathrm{~h} / \mathrm{w} *$ jint & & & & & -0.09 & -0.23 to 0.05 \\
\hline & $35-40 \mathrm{~h} / \mathrm{w} *$ jint & & & & & -0.10 & -0.35 to 0.14 \\
\hline \multirow[t]{4}{*}{ Unconstrained } & $\leq 20 \quad \mathrm{~h} / \mathrm{w} * \mathrm{jint}$ & & & & & -0.01 & -0.10 to 0.07 \\
\hline & $21-34 \mathrm{~h} / \mathrm{w} *$ jint & & & & & -0.10 & -0.16 to -0.05 \\
\hline & $41-47 \mathrm{~h} / \mathrm{w} *$ jint & & & & & 0.06 & -0.76 to 0.21 \\
\hline & $\geq 48 \quad \mathrm{~h} / \mathrm{w} *$ jint & & & & & 0.08 & -0.00 to 0.24 \\
\hline
\end{tabular}




\begin{tabular}{|c|c|c|c|c|c|c|c|}
\hline \multirow[t]{5}{*}{ Overemployed } & $\leq 20 \quad \mathrm{~h} / \mathrm{w} * \mathrm{jint}$ & & & & & -0.06 & -0.25 to 0.13 \\
\hline & $21-34 \mathrm{~h} / \mathrm{w} *$ jint & & & & & -0.03 & -0.17 to 0.11 \\
\hline & $35-40 \mathrm{~h} / \mathrm{w} *$ jint & & & & & -0.00 & -0.07 to 0.06 \\
\hline & $41-47 \mathrm{~h} / \mathrm{w} *$ jint & & & & & -0.09 & -0.19 to 0.02 \\
\hline & $\geq 48 \quad \mathrm{~h} / \mathrm{w} * \mathrm{jint}$ & & & & & -0.02 & -0.21 to 0.17 \\
\hline \multirow[t]{4}{*}{ Contextual } & Trade unions & 0.01 & -0.09 to 0.11 & 0.02 & -0.07 to 0.11 & 0.02 & -0.07 to 0.11 \\
\hline & Social spending & 0.00 & -0.00 to 0.00 & 0.00 & -0.00 to 0.00 & 0.00 & -0.00 to 0.00 \\
\hline & Unemployment & 0.08 & -0.23 to 0.40 & 0.33 & 0.04 to 0.61 & 0.32 & 0.05 to 0.60 \\
\hline & Part-time & 0.16 & -0.06 to 0.38 & 0.19 & 0.01 to 0.39 & 0.19 & -0.01 to 0.39 \\
\hline \multirow[t]{2}{*}{ Random effects } & Sd Constant & 3.04 & 2.39 to 3.86 & 2.88 & 2.35 to 3.52 & 2.88 & 2.35 to 3.52 \\
\hline & Sd Residual & 18.98 & 17.41 to 20.70 & 17.90 & 16.44 to 19.49 & $\begin{array}{l}17.84 \\
0.13\end{array}$ & 16.36 to 19.45 \\
\hline
\end{tabular}

All models adjusted by age, children, living with a partner, breadwinner, disabled/ill partner, older than 70 years, foreign born, urban, education level, earnings, tenure, occupation, economic sector.

LR-test comparing interaction and adjusted models

Omitted output for underemployment women above $40 \mathrm{~h} / \mathrm{w}$ due to low sample size. 
Annex.

Table A1. Descriptive statistics

\begin{tabular}{|c|c|c|c|c|c|c|c|c|c|c|}
\hline & \multirow{2}{*}{\multicolumn{2}{|c|}{$\begin{array}{c}\text { Men } \\
(\mathrm{N}=9,345)\end{array}$}} & \multirow{2}{*}{\multicolumn{2}{|c|}{$\begin{array}{c}\text { Women } \\
(\mathrm{N}=10,998)\end{array}$}} & \multicolumn{3}{|c|}{ Men } & \multicolumn{3}{|c|}{ Women } \\
\hline & & & & & \multirow[t]{2}{*}{ Under. } & \multirow{2}{*}{$\begin{array}{l}\text { Uncons- } \\
\text { trained }\end{array}$} & \multirow[t]{2}{*}{ Over. } & \multirow[t]{2}{*}{ Under. } & \multirow{2}{*}{$\begin{array}{l}\text { Uncons- } \\
\text { trained }\end{array}$} & \multirow[t]{2}{*}{ Over. } \\
\hline & $\%$ & sd. & $\%$ & sd. & & & & & & \\
\hline Mental well-being* & 69.1 & 18.8 & 67.1 & 19.9 & 68.0 & 71.2 & 65.5 & 65.6 & 69.7 & 62.0 \\
\hline \multicolumn{11}{|l|}{ Age } \\
\hline $28-35$ & 24.3 & 42.8 & 24.4 & 42.9 & 31.0 & 24.0 & 22.6 & 25.2 & 24.1 & 24.5 \\
\hline $36-45$ & 33.8 & 47.3 & 34.3 & 47.5 & 35.4 & 33.0 & 35.0 & 35.5 & 34.4 & 33.5 \\
\hline $46-58$ & 41.9 & 49.3 & 41.3 & 49.2 & 33.6 & 43.0 & 42.4 & 39.3 & 41.5 & 42.0 \\
\hline \multicolumn{11}{|l|}{ Breadwinner } \\
\hline Yes & 83.2 & 37.4 & 39.4 & 48.9 & 20.0 & 10.0 & 11.1 & 61.1 & 54.4 & 46.1 \\
\hline No & 11.3 & 31.6 & 53.1 & 49.9 & 72.9 & 84.0 & 84.8 & 36.4 & 37.0 & 46.3 \\
\hline Equally & 5.5 & 22.9 & 7.5 & 26.3 & 7.1 & 6.0 & 4.1 & 2.5 & 8.6 & 7.6 \\
\hline Partner & 76.3 & 42.6 & 73.9 & 43.9 & 68.1 & 76.7 & 77.8 & 67.4 & 75.0 & 74.9 \\
\hline Children $<2 \mathrm{y}$ & 8.3 & 27.6 & 7.9 & 27.1 & 11.3 & 8.0 & 8.0 & 7.2 & 7.6 & 9.2 \\
\hline Children 3-6y & 13.6 & 34.3 & 14.3 & 35.0 & 15.9 & 12.6 & 15.0 & 14.4 & 13.8 & 15.2 \\
\hline Children 7-12y & 19.4 & 39.5 & 21.7 & 41.2 & 18.2 & 18.4 & 21.5 & 24.7 & 20.6 & 22.6 \\
\hline Children 13-15y & 10.8 & 31.1 & 12.7 & 33.4 & 8.5 & 10.9 & 11.4 & 16.6 & 12.4 & 11.5 \\
\hline Older $>70 y$ & 3.1 & 17.3 & 3.6 & 18.6 & 4.5 & 3.2 & 2.6 & 3.9 & 3.6 & 3.4 \\
\hline Ill or disabled & 1.4 & 11.7 & 1.6 & 12.7 & 2.0 & 1.3 & 1.2 & 2.5 & 1.6 & 1.2 \\
\hline Immigrant & 9.0 & 28.6 & 8.1 & 27.3 & 19.4 & 7.3 & 9.0 & 12.2 & 6.8 & 8.9 \\
\hline Urban & 42.0 & 49.4 & 40.0 & 49.0 & 46.5 & 39.7 & 44.7 & 40.6 & 37.9 & 44.4 \\
\hline Intermediate & 34.4 & 47.5 & 35.3 & 47.8 & 29.8 & 34.5 & 35.5 & 33.4 & 36.2 & 34.4 \\
\hline Rural & 23.6 & 42.5 & 24.7 & 43.1 & 23.7 & 25.8 & 19.8 & 26.0 & 25.9 & 21.2 \\
\hline \multicolumn{11}{|l|}{ Education } \\
\hline University & 22.8 & 41.9 & 26.9 & 44.3 & 15.1 & 21.1 & 28.2 & 17.9 & 24.8 & 36.4 \\
\hline Short tertiary & 14.1 & 34.8 & 16.5 & 37.1 & 13.3 & 12.8 & 16.8 & 15.1 & 15.5 & 19.5 \\
\hline High secondary & 47.3 & 49.9 & 43.5 & 49.6 & 45.7 & 50.8 & 41.1 & 43.8 & 47.6 & 34.3 \\
\hline Low secondary & 13.5 & 34.2 & 11.1 & 31.4 & 21.1 & 12.9 & 12.4 & 19.3 & 10.2 & 8.6 \\
\hline Primary or less & 2.3 & 15.1 & 2.0 & 13.9 & 4.8 & 2.4 & 1.5 & 3.9 & 1.9 & 1.2 \\
\hline \multicolumn{11}{|l|}{ Tenure } \\
\hline More than $3 y$ & 73.4 & 44.2 & 70.6 & 45.6 & 49.8 & 75.9 & 75.6 & 54.6 & 72.3 & 75.3 \\
\hline $2-3 y$ & 12.5 & 33.0 & 14.2 & 34.9 & 20.0 & 11.2 & 12.6 & 17.8 & 14.4 & 12.0 \\
\hline 1 or less & 13.1 & 33.8 & 14.0 & 34.7 & 27.5 & 11.9 & 11.2 & 27.0 & 12.0 & 11.6 \\
\hline Missing & 1.0 & 10.1 & 1.2 & 10.7 & 2.7 & 1.0 & 0.6 & 0.6 & 1.3 & 1.1 \\
\hline \multicolumn{11}{|l|}{ Income } \\
\hline Low & 30.8 & 46.2 & 34.7 & 47.6 & 38.9 & 30.2 & 29.6 & 34.7 & 34.4 & 35.3 \\
\hline Medium & 36.4 & 48.1 & 32.7 & 46.8 & 31.5 & 36.0 & 38.3 & 33.6 & 33.6 & 30.3 \\
\hline High & 32.8 & 47.0 & 32.6 & 46.9 & 29.6 & 33.8 & 32.1 & 31.7 & 32.0 & 34.4 \\
\hline
\end{tabular}

sd.: standard deviation; Under.: underemployed; Over.: overemployed

*mean values. Output on occupation and sector omitted 